\title{
Violence against Women as Reflected in the Polish Television Series A Second Chance
}

\author{
Aleksandra M. Różalska \\ Department of American Studies and Mass Media \\ Women's Studies Centre \\ Faculty of International and Political Studies \\ University of Lodz
}

DOI: http://dx.doi.org/10.18778/1733-8069.16.1.03

\section{Keywords:}

violence, women,

television, A Second

Chance, sexual

harassment, victim, perpetrator

\begin{abstract}
The aim of this article is to provide a critical reflection on contemporary Polish television series, in particular the ways in which they tackle narratives that include instances of violence against women (VAW). The analysis is based on the example of the show titled Druga szansa (A Second Chance), broadcast in 2016-2018 by a commercial network TVN. Recent research shows that there are some common, repetitive ways in which media represent violence against women, its circumstances and reasons, as well as the portrayals of victims and perpetrators. The author looks at VAW in the selected television series in the context of the \#MeToo movement and of the gender-related debates in Poland. The conclusion is that the chosen television series considers VAW as a serious social problem and has the potential to sensitize audiences by representing it in an unbiased, complex, and nuanced way. However, it fails to address its wider socio-cultural aspect resulting from patriarchal structures and gender inequality.
\end{abstract}

Dr. Aleksandira M. Różalska is an Assistant Professor at the Department of American Studies and Mass Media and Head of the Women Studies Centre, University of Lodz. She is a local coordinator of Erasmus Mundus Master's Degree in Women's and Gender Studies (GEMMA). In 2015-2019, she was Principal Investigator for the Horizon 2020 project Gender and Cultures of Equality in Europe (GRACE). In 2005-2006, she was a Fulbright fellow at the American University, Washington DC. She lectured at various European and American universities, among others at Roehampton University (UK), University of Oviedo (Spain) and Primorska University in Koper (Slovenia), Florida International University (Miami, USA), Rutgers University (New Jersey, USA), and Wittenberg University (Ohio, USA). Apart from studies on media discourses and minorities in Europe and in the US, her research interests include: media and intercultural education of disadvantaged groups; education through art; intersections of gender, race, and religion in the media; relationships between the media and politics; narratives of $9 / 11$ and the war on terror; and media representations of refugees and migrants. She has published on images of minorities and women in (American and Polish) film and television as well as on cultural representations of 9/11 and its aftermath. She co-edited four volumes devoted to feminisms in various cultural contexts as well as on contemporary perceptions of subjectivity and difference in Europe and the US. Currently, she is working on a book on the post-9/11 television discourses from postcolonial and feminist perspectives, as well as on a journal article about television representations of abortion in Poland and the US.

\section{Contact details:}

Department of American Studies and Mass Media Women's Studies Centre

Faculty of International and Political Studies

University of Lodz

ul. Narutowicza 59a, 90-131 Łódź, Poland

email address: aleksandra.rozalska@uni.lodz.pl 
For all types of violence, the commonality is a quest for power.

Kilmartin and Allison, Men's Violence against Women

he aim of this article is to provide a crit-
ical reflection on contemporary Polish
television series, in particular the ways
in which they tackle narratives that include instances of violence against women (VAW). The analysis is based on the example of the show titled Druga szansa (A Second Chance), broadcast in 2016-2018 by a commercial network TVN. In particular, I am interested in how this television production represents sexual, physical, and psychological violence in intimate relationships and sexual harassment in the workplace.

Not surprisingly, my paper was inspired by the \#MeToo movement, both in the United States and in Poland, and its diverse media representations. Theoretically, it derives from recent feminist scholarship on anti-gender movements in Europe in general, and in Poland in particular (Patternote and Kuhar 2017 Kováts and Pőim 2015) as well as on patriarchal (public and media) discourses determining socio-cultural perception of family, motherhood, gender roles, and women's rights (Różalska 2011). Taking into consideration a wider socio-political context, I will be looking into the selected television series, intending to elaborate on whether it in any way reflects the public debate on the socalled 'gender ideology', initiated by the Catholic Church and Christian-conservative politicians. I will also refer to the long-lasting debate and political tensions over the ratification of the Istanbul Convention (The Council of Europe Convention on Preventing and Combating Violence Against Women and Domestic Violence) and to the controversies connected therewith regarding the perceptions of family, gender stereotypes, and violence against women. Finally, I would like to link the narratives on VAW with mass protests against violating basic women's rights (not only reproductive ones) in 2016 (Graff and Korolczuk 2017) that seem to dominate some of the concerns and challenges to women's rights in Poland.

The choice of the television series titled A Second Chance, which belongs to the genre of dramatic series, is not accidental. I have focused on two seasons of the show (the second and the fifth) as these parts of the production tackle the issue of violence against women and hence provide an important comparative value in the context of the \#MeToo movement. Both the show producers and the leading actress of A Second Chance (Małgorzata Kożuchowska) on numerous occasions underlined the importance of the problem undertaken in the fifth season and the fact that it was not chosen randomly; they wanted the topic that would be "up-to-date, strong, and surprising." ${ }^{\prime 1}$ As the actress said,

I hope the season will be an important voice in the public debate; we expect our viewers to speak up and comment on this very difficult issue. (...) I would also like to emphasize that we are not going to divide the world into the evil and violent male land, and the sensitive, beautiful and subtle women's land, as we are showing different images of men and women, who are paradoxically not always supportive and emphatic to each other, as we would hope they are. ${ }^{2}$

\footnotetext{
1 "Małgorzata Kożuchowska: the \#MeToo thread in A Second Chance will be a voice in a discussion on a very difficult matter. We want to show various faces of women and men" (https:// www.wirtualnemedia.pl/artykul/malgorzata-kozuchowska-watek-metoo-druga-szansa-sezon-5, translation mine).

${ }^{2}$ See: https://www.wirtualnemedia.pl/artykul/malgorzata-kozuchowska-watek-metoo-druga-szansa-sezon-5, translation mine.
} 
Throughout its five-season run, A Second Chance was watched on average by almost 1.8 million peo$\mathrm{ple}^{3}$ and those ratings count only television viewers, excluding recipients using the TVN's Player+ online platform, which, according to the Wirtualne Media portal, reached 9.5 million views during the first season. ${ }^{4}$ Although television family-sagas such as M jak mitość or Na Wspólnej undoubtedly achieved higher ratings, the two genres cannot be easily compared as they are targeted at different type of viewers. Furthermore, TVN offers shows that are popular among younger viewers (in comparison to similar genre series at other television stations). For example, the fifth season of $A$ Second Chance ranked second among general audience (with the average audience of 1.58 million people ${ }^{5}$ ), but was the most popular among younger viewers, namely those aged $16-49 .^{6}$

It is worth mentioning that TVN aspires to produce shows that are considered quality television, although it is, of course, debatable whether A Second Chance fits in the definition of quality TV, which is a term widely used nowadays by media researchers and critics in reference to television series that are of a higher quality (in terms of content, style, aesthetics, etc.), thus requiring more demanding viewers. Ratings are not the most important goal of quality television. Instead, satisfying the tastes of more sophisticated audiences is the main objective. As Sarah Cardwell rightly points out, "Quality televi-

\footnotetext{
${ }^{3}$ My own calculation on the basis of the ratings of each season. 4 "A Second Chance is a hit of TVN and Player.pl. The second season will be made" (https://www.wirtualnemedia.pl/artykul/ druga-szansa-hitem-tvn-i-player-pl-powstanie-drugi-sezon, translation mine).

5 "The last season of A Second Chance lost 280,000 viewers" (https://www.wirtualnemedia.pl/artykul/koniec-serialu-druga-szansa-ogladalnosc-piaty-sezon, translation mine).

6 See: https://www.wirtualnemedia.pl/artykul/koniec-serialu-druga-szansa-ogladalnosc-piaty-sezon, translation mine.
}

sion may be perceived as being good for its viewers - morally or educationally edifying - but it may still be experienced as worthy, dull, conventional or pretentious" (2007:21). If approached from this perspective, A Second Chance is, in my view, good for its viewers as it tackles a socially important problem in a relatively in-depth way. However, its reception by the audiences may vary (as the ratings indicated).

Significantly, what is considered quality television differs between various national and social contexts as critics appreciate different characteristics and values in Great Britain, where the emphasis is put on liberal educated audiences, stylistic complexness, sophisticated content, and psychological in-depthness (Seiter and Wilson 2005:139; see also Feuer 1984); in the United States, where the expressions "good television" and "quality television" are often considered synonymous (as elaborated on in Quality TV. Contemporary American Television and Beyond by Janet McCabe and Kim Akass); or in Scandinavian countries, whose productions are often labelled 'Nordic Noir' for their gloomy, dark, often disturbing atmosphere, uneasy plots and complex, multidimensional protagonists (Rustad 2015:1-2). Interestingly and surprisingly, some scholars also consider soap opera or day-time drama (genres traditionally regarded as "low," i.e. less demanding and not serious) as quality television (Seiter and Wilson 2005). I find the American approach to quality television the most relevant in my research due to the fact that, as Cardwell (2007:26) writes, US productions

are likely to explore 'serious' themes, rather than representing the superficial events of life; they are likely to suggest that the viewer will be rewarded for seeking out greater symbolic or emotional resonance within the details of the programme. American quality television also tends to focus on the present, offer- 
ing reflections on contemporary society, and crystallising these reflections within smaller examples and instances.

The way I see it, A Second Chance explores a serious theme, rewards the viewer with emotional engagement as well as brings up a very timely and socially important problem.

As mentioned above, this article focuses on a popular television series $A$ Second Chance with regard to images of violence against women as reflected in this show. The particular questions I intend to address are: how is VAW represented in this production and what purposes do these images serve? Secondly, I wish to examine the quality of the narratives on VAW, i.e. are they legitimizing, ridiculing, belittling the experiences of VAW? Worth investigating is also whether they treat VAW as a serious social problem and have the potential to sensitize audiences by representing it in an unbiased, complex, and nuanced way, including looking at VAW not as incidental, individual problem, but, rather, as a socio-cultural phenomenon resulting from patriarchal structures and gender inequality. In line with the critical media discourse analysis applied in this paper, I ask whether the power elites - and this is what television undoubtedly is - "enact, sustain, legitimate, condone or ignore social inequality and injustice" (van Dijk 1993:252).

The main methodology applied in this article includes qualitative research consisting in qualitative content analysis of television series in combination with critical media discourse analysis. In my research (as much here as in my other works on discriminatory practices against women as reflected in television), I derive from Teun A. van Dijk, a critical discourse researcher who conceives of critical dis- course analysis as "problem- or issue-oriented rather than paradigm-oriented. Any theoretical or methodological approach is appropriate as long as it is able to effectively study relevant social problems, such as those of sexism, racism, colonialism and other forms of social inequality" (1995:17). Ruth Wodak (2013:xxxvii) adds that there are some key characteristics of critical discourse analyses, also crucial for this article, namely theoretical eclecticism (inspiration derived from a wide range of theoretical scholarship), interdisciplinarity (needed in order to be able to comprehend complex social processes), no accepted canon of data collection (data may come from many sources), and, finally, specific problem-orientated research.

Van Dijk insists that "when studying the role of discourse in the society, CDA especially focus on (group) relations of power, dominance and inequality and the ways these are reproduced or resisted by social group members through text and talk" (1995:18). This approach is applied in my research. Specifically, I begin by identifying the dominant discourses of violence against women in the media globally and locally, and then I investigate whether the selected TV series reproduces or resists them. As LI Qianbo claims, "CDA plays a crucial part in revealing implicit prejudice and discrimination in society; it attaches importance not only to the linguistic structures and their meanings, but also to their application in the social context" (2016:40), which is in line with van Dijk's perspective that "CDA should deal primarily with the discourse dimensions of power abuse and the injustice and inequality that result from it" (1993:252). In other words, "The study of discourse mediates between society/culture/situation, cognition and discourse/language" (Wodak 2013:xxxii). There are various approaches to the media within critical discourse analysis, but what unites them all 
"is a shared interest in social processes of power, hierarchy building, identity politics, globalisation and glocalisation, inclusion/exclusion and subordination (Wodak 2013:xxxvii).

Importantly for my research, José María Bernardo Paniagua et al. contend that the focus of critical media analysis "should be on how wider changes in society and culture are manifest in changing media discourse practices. (...) The relationship between texts and society/culture is to be seen dialectically. Texts are socioculturally shaped but they also constitute society and culture, in ways which may be transformative as well as reproductive" (2007:7).

Last but not least, this paper also derives inspiration from qualitative sociologists, who believe that "visual grounded theory as the methodology deserves to grow and develop. The main reason is the 'visual turn', which has emerged in our times. We have to deal with increasingly numerous artefacts and visual processes in our everyday life," and hence the need to focus research on "the visuality of our social worlds" (Konecki 2011:152). The choice of this methodological framework results from the specific objective behind this work, which is oriented at identifying characteristic discursive elements in the narratives on violence against women and determining how victim/perpetrator figures and the dominant power relations are situated within these cultural texts. Critical discourse analysis, on the other hand, enables one not only to examine meanings, basic concepts and expressions, narrative strategies as well as modes of representing VAW offered by the selected television series, but also to situate them within wider socio-political contexts as cultural phenomena that are informed by larger processes within society. It also allows for reflection on whether these texts reproduce or, rather, contest the dominant imagery of VAW and hence, as van Dijk writes, critical discourse analysis "focuses on the relations between discourse and society (including social cognition, politics and culture)" (1995:17).

\section{Violence Against Women and Its Socio- Political Reception}

Within the last forty years there has been extensive research on violence against women that started to be discussed publicly as an important social problem and also elaborated on the international level during debates on women's rights violations worldwide. One of the groundbreaking contributions was Lenore Walker's book titled Battered Women (1979), which introduced the concept of a cycle of violence in intimate relationships. The cycle is divided into three main levels: honeymoon phase, tension phase, and explosion phase (Walker 1979 as cited in Kilmartin and Allison 2007). This view has completely changed the perception of VAW from incidental to recurring.

Another important development was the 'Power and Control Wheel' tool, which introduced certain socio-psychological contexts of violence against women, such as isolation, emotional abuse, economic abuse, sexual abuse, using children, issuing threats, using male privilege, intimidation (Kilmartin and Allison 2007:19). More recent models (Kilmartin and Berkowitz 2005) describe the problem further, claiming that there are three important contexts to be considered, namely that "there is pathology on the part of the perpetrator, there is a decision to act violently and, importantly, there is a favorable social context that supports male dominance" (Kilmartin and Allison 2007:21). All of these aspects find their reflection in media representations of VAW. 
The Council of Europe Convention on preventing and combating violence against women and domestic violence, also known as the Istanbul Convention (2011), provides the following definition of violence against women:

'[v]iolence against women' is understood as a violation of human rights and a form of discrimination against women and shall mean all acts of gender-based violence that result in, or are likely to result in, physical, sexual, psychological or economic harm or suffering to women, including threats of such acts, coercion or arbitrary deprivation of liberty, whether occurring in public or in private life.

In many interpretations of VAW as well as in international documents, it is underlined that "the convention leaves no doubt: there can be no real equality between women and men if women experience gender-based violence on a largescale and state agencies and institutions turn a blind eye."

Violence against women is nowadays recognized as a global problem that transgresses cultural, socio-political, ideological, and economic differences between particular countries. As the already quoted Christopher Kilmartin and Julie Allison define the phenomenon, "In addition to rape or sexual assault, it includes (a) intimate partner violence (IPV), (b) sexual harassment, (c) stalking, (d) trafficking, (e) forced prostitution, (f) exploitation of labor, (g) debt bondage of women and girls, (h) sex-selective abortion, (i) physical and sexual violence against prostitutes, (j) female infanticide, (k) the deliberate neglect of girls relative to boys, and (l) rape in war" (2007:5). Researchers continue

\footnotetext{
7 “About the Convention." Retrieved October 5, 2018 (https://www. coe.int/en/web/istanbul-convention/about-the-convention).
}

to add other important dimensions to the definition above. As can be concluded, "Gender-based violence is any attack directed against a (usually female) person due, at least in part, to a disadvantaged position within male-dominated social systems. The context that serves to support the current epidemic of men's violence against women is embedded within a complicated web of privilege, toxic masculinity, and patriarchy" (Kilmartin and Allison 2007:5).

Certain characteristics of violence against women have emerged from the research on VAW, which will be reflected in the analyzed television series. As far as sexual violence is concerned, such acts of violence are often not unique episodes, but are ongoing over time (for example in intimate relationships). Secondly, more often than not, sexual violence is perpetrated by someone the woman is familiar with, not by a stranger (so the perpetrator knows the victim and often does not own up to his crimes, nor is punished for them). Thirdly, the victim is treated with suspicion and disbelief, sometimes even by people close to her; consequently, such crimes often go unreported (Kilmartin and Allison 2007:4).

I would also add that VAW is very often tabooed, silenced, or even denied by the patriarchal socio-political systems, which is exemplified by the case of Poland. According to Weronika Grzebalska (2015), the Council of Europe Istanbul Convention was one of the triggers of the recent wave of anti-gender campaign in Poland, which began in 2012-2013. The current government activities seem to confirm this statement as the Parliament promised to withdraw from the Polish ratification of the Convention and significantly cut funding for NGOs helping women (predominantly victims of domestic violence and sexual harassment). 
Interestingly and paradoxically, the critical reception of the government's actions, the Black Protest of 2016 as well as the \#MeToo movement all contributed to the fact that the mainstream media in Poland started to be interested in certain aspects of women's rights (not out of pure interest in women's issues, I believe, but due to the fact that the media want to situate themselves in opposition to the dominant power and the Christian-conservative government).

Before I proceed to analyze the example of such increased media attention in the form of the TV series A Second Chance, I shall outline the existing research on media representations of VAW.

\section{Media Representations of VAW}

Research shows that there are some common, repetitive ways in which media represent violence against women, its circumstances and reasons, as well as the portrayals of victims and perpetrators. I will briefly summarize these schematic modes of media coverages of VAW.

First, the vast majority of the reporting on violence against women are covered as "incidents," focusing on tragic, dramatic circumstances without an in-depth explanation of the reasons. An example of such a statement is, for instance, "that violence perpetrated against women is gender-based and rooted in the social phenomena of gender inequality" (Sutherland et al. 2015:12). Additionally, the focus on individual incidents of VAW is accompanied by "episodic framing," which can be understood as the lack of "the broader public's understanding of the issue, [which] could be improved by the inclusion of more expert sources, including domestic violence advocates and those with lived experience of violence" (Sutherland et al. 2016). ${ }^{8}$

Second, media react more eagerly to "serious" instances of VAW, namely that which "contributed to a 'murder centric' frame of most reporting, which is no doubt newsworthy but does not necessarily reflect women's different experiences of violence. (...) Other types of violence, including emotional, threats or sexual harassment were all but invisible" (Sutherland et al. 2016). "Murder-centrism" is connected to sensationalism that characterizes both news and fictional coverage of VAW: "Sensationalism in the news is often defined in terms of its capacity to provoke attention or arouse certain emotional responses in viewers. It shares much in common with 'newsworthiness'"' (Sutherland et al. 2015:14). Similarly, film and television productions also often display male violence against women as a core narrative element, depicting the violent act as abnormal and not as a daily occurrence in women's lives; such images sensationalize the incidents and eroticize the victims.

Third, media coverages of VAW are still not free from certain myths and misrepresentations, with victim-blaming being the most frequent manifestation thereof (Schwartz 1997). This phenomenon refers "to circumstances in which victims of crime are portrayed so that it appears they are partially or entirely responsible for the transgressions committed against them" (Sutherland et al. 2015:17). Victim-blaming includes arguments such as "she was drinking, flirting/went home with the perpetrator, was out alone, they were arguing" (Sutherland et al. 2016:not known). Moreover, it is often alluded that

${ }^{8}$ https://www.anrows.org.au/publication/media-representations-of-violence-against-women-and-their-children-final-report/. 
the woman does not say "no" enough, therefore suggesting that sexual intercourse is consensual. As Kilmartin and Allison capture it, "Consensual means 'mutually agreed upon'; therefore, if one person thinks that the act is consensual and the other does not, it is not consensual" (2007:5). Connected with it is also another misconception, namely that the responsibility for prevention lies on women's side. The media "implicitly, and sometimes explicitly, imply that women should modify their behavior in the face of such warnings including where to go, when to go, what to wear, how long to stay out, how much to drink and who to go with" (Sutherland et al. 2015:18). What is more, "one of the most enduring myths sustained by media is that women living with abusive and violent partners are responsible for the violence because they did not leave the relationship" (Sutherland et al. 2015:18). Meanwhile, as Jalna Hanmer underlines, "Emotional abuse coexists with these more physical forms which further undermine women's sense of personal worth and competence. The way that forms of violence and abuse suffuse every aspect of women's lives makes it difficult for women to emerge from what is best understood as abusive system of social relations" (Hanmer 1996:9).

Research on VAW focuses separately on the socalled "rape myths" that are based on the false assumption of "stranger danger" described above, as well as on the process of othering of both the victim and the perpetrator. With regard to victims, "a number of studies showed that depictions of 'otherness' were often used by media when women deviated from their stereotypical female role [...] including descriptions of female 'victims' as promiscuous, welfare dependent, with underworld dealings, as mail order brides, dangerous, manipulative, antisocial, eccentric, deranged or mentally ill" (Sutherland et al. 2015:16; see also Koss and Cleveland 1997). The othering of rapist consists in describing them as "monsters, sick, insane, disturbed, evil or deviant in a way that reinforces the notion that sexual violence can be attributed to wayward individuals rather than cultural and social phenomena" (Sutherland et al. 2015:16). What is more, media coverages often represent "rape as an anomaly that only happens outside of normative white society. [...] Rape perpetrated by a male current, former or dating partner remained largely invisible in the media" (Sutherland et al. 2015:16).

This finally brings me to my last point, i.e. the perpetrator, who is missing from many media reports. Alternatively, the perpetrator's behavior is explained rationally: "Incident-based reporting offers excuses for the perpetrator, like he was drinking, using drugs, jealous/seeking revenge, 'snapped' or 'lost control'"' (Sutherland et al. 2016:not known). Not only is the perpetrator invisible in media narratives, but he is also missing from a larger context of disturbed power relations: "Those males who commit gendered violence often believe in men's general superiority over women, and their own superiority over specific women" (Kilmartin and Allison 2007:8). However, the connection to unequal power relations contributing to violence is completely absent from the media as "overly-sensational news frames tend to minimize the social context while drawing attention to isolated incidents. [...] An over-reliance by journalists on law enforcement as sources of information may result in details about women that inadvertently place their behavior, demeanor or conduct as contributing to violence perpetrated against them" (Sutherland et al. 2015:12).

Summing up my observations in this section, violence against women in the media is portrayed as 
incidental and on the individual level rather than as a systemic problem within the (patriarchal) society. Both in fictional programs and in the news, VAW - particularly domestic violence and sexual harassment at work - is represented as something exceptional, incidental, abnormal, and, most of all, rare. I believe that by dint of the \#MeToo movement this has started to change; women worldwide began to talk about the everydayness and commonness of violence as well its relationship to power, toxic masculinity, and patriarchy.

Importantly, feminist media critics have been also pointing to yet another aspect of the portrayal of VAW - especially sexual violence represented in a sensationalized and eroticized way - by asking a question about whether it is "a justified look at violence against women or a crude plot device" (Hughes 2014:not known). For example, the television series titled Game of Thrones (2011-2019) has evoked controversies over its depictions of rape. Some reviewers (e.g., Orr 2015) criticized it for featuring too much sexual violence, often very brutal, towards women and young girls:

To some extent, the HBO show is adapting the themes of the novels, but it also deliberately added instances of rape and torture on a number of occasions. The creators have gone out of their way, time and time again, to ramp up the sexual violence well beyond their source material. New characters have been invented in order to become victims (or victimizers), and existing ones have had their sexual cruelty amplified.

In my opinion, the show mastered the use of rape as a plot twist or cliff hanger, making it increasingly disturbing for the audience to watch. Even though in some cases rape and women's suffering leads to their rise and victory, and facilitates "revenge" sto- ries, the representation of violence is instrumental, simplistic, and undoubtedly harmful for rape survivors.

On the other hand, there are other shows - such as The Handmaid's Tale (2017-date), Top of the Lake (2013, 2017), Happy Valley (2014-2016), Unbelievable (2019) to name but a few - that move away from representing sexual violence against women from men's perspective and for men's pleasure. As Amanda Hess (2017) underlines,

[t]he rape of a woman, or its implication, has long been used as an inciting incident in film. The effects of rape on its victims are complex, lasting and largely misunderstood. Doing justice to the offense requires a depth of insight into the crime and the time to tell it all. For decades, films have staged rapes of women, then directed their attention to some man's story instead. We're just beginning to see what it looks like when the camera doesn't turn away.

As the examples of Top of the Lake and Unbelievable show, television narratives have a great potential in fair and complex representing violence against women and making rape culture prevail as an inseparable part of patriarchy (Anderson and Doherty 2008). They succeed in depicting patriarchy and misogyny as pathological and criminogenic (Talarczyk 2013).

\section{Polish Television Series and VAW}

Research on television representations of VAW in Poland are scarce except for studies by a sociologist, Beata Łaciak, who was monitoring the selected television series in this context (2013). I will shortly summarize her observations, which, to a certain extent, confirm the above considerations on stereotypical depictions of VAW. 
As in real life and the news, television series represent only individual cases of VAW, which is why they focus on 'extreme' incidents instead of explaining reasons and consequences of violence in a wider social context. Although victims -especially those of domestic violence -usually get support from families and friends, their situation is shown in sympathetic ways, and aggression against them is condemned, it is very seldom the case that crimes against them are reported to the police. Other institutions (such as NGOs or psychological centers) are hardly ever involved in helping the victims. Not only are women reluctant to punish the perpetrator, but it is also people in their surroundings who do not encourage them to do so, treating domestic violence or rape as something that women should be ashamed of (Łaciak 2013:194-195).

Importantly, VAW in television series is not associated only with the so-called "pathological" environments; it also happens in affluent families, while perpetrators are often professionally and financially successful and socially respectable men. However, physical and sexual violence is very often associated with overdosing alcohol (Łaciak 2013:194), which can sometimes be understood as a sort of excuse for the violent behavior. Nonetheless, the analyzed television series do not focus on physical violence exclusively, which reflects the existing research on VAW: "With known men, a combination of abuse is always present, although these can be merged or separate, sporadic or constant. For women, violence includes emotional, sexual and physical [and economic] forms, including threat" (Hanmer 1996:9).

Generally speaking, Łaciak's research shows that "the victim syndrome" and the circle of violence are both represented realistically. While in the past the perpetrator could miraculously change - "heal" himself from aggressive inclinations without any help from third parties - and women were always patient, loving, forgiving, and ready to give a second chance, such a way of representing the matter has recently started to gradually alter. Over the last few years (since mid-2000s), violence is more strictly condemned, women are supported by their family and friends, and they are encouraged to leave the toxic relationship rather than to save it. Furthermore, violence is shown not as incidental, but as a long-term problem (Eaciak 2013:196). However, it isstill not directly linked to the patriarchal foundations of the society.

Despite these more complex images of the process of escalation of violence in intimate partnerships, depictions of victims are still very schematic. They encompass a variety of stereotypes-women are either helpless and deprived of any subjectivity or represented in an unsympathetic way. Importantly, violence is often a punishment for improper behavior or for transgressing socially accepted roles, so victim blaming is still a popular explanation for VAW, which implies that women deserve to be treated violently (Łaciak 2013:197).

Interestingly, although instances of physical and emotional violence in television series take place in the family and intimate relationships, sexual violence including rape is represented as happening outside of the family (Łaciak 2013:198). Apparently, martial rape is still a tabooed matter, also largely due to the misunderstanding as to what sexual violence is: "For most men, what is usually called 'sexual violence' is not included in accounts of violence to know women. Except for the special case when a man has been arrested and charged for rape, men rarely define coercive sex and pressurized sex as violence to women" (Hearn 1996:28). 
There is one more simplification with regard to rape that Łaciak identifies: rape victims get over trauma relatively quickly and without external help (2013:199), which is against the existing research on the consequences of rape and the importance of the involvement of others (Hanmer 1996). As Hanmer (1996:19) underlines,

[t]he involvement of others in areas of struggle in which women, and often children, are primary targets, both contributes to patterns of dispute and of resistance. How others are brought in and by whom, what they do, how cultural forms are used (beliefs, norms, etc.) and why others intervene (...) are major contributory factors in creating differences between women and in women's individual situations when facing violence in the home. This is why it matters so much how others respond. (...) If you are not part of the solution, you are part of the problem; there is no neutral ground to which one, whether agency or individual, can withdraw.

Such a perspective is completely missing from the media representations of VAW. Instead, television prefers to emphasize that rape is often difficult to prove and its circumstances are unclear, so even if victims want to report it, they have difficulty in convincing others of their version of the story (Eaciak 2013:200). Secondly - and this is a very popular plot - women often falsely accuse men of rape or sexual harassment (out of jealousy, revenge, etc.). I consider this a very problematic narrative solution as it may contribute to an overall impression that women cannot be trusted and that they endanger innocent men by accusing them of misconduct.

\section{Druga szansa (A Second Chance)}

I shall now turn to a more recent example of a television series, which to a certain extent confirms - but also tries to transgress - the schematic media images of violence against women described above. A Second Chance's main protagonist, Monika Borecka, is a well-known television producer and celebrity manager. She co-operates with major television stations, has her own star-managing company, and in the final season she is the chief editor of a popular women's magazine. In other words, she operates within show business and celebrity world on a daily basis.

A Second Chance features two major plots connected with violence against women. The way I see it, the first one was dealt with in a very stereotypical way, while the second one covered the problem in a much more detailed and complex manner. I ascribe this difference to the popularity of the \#MeToo movement, which resulted in the producers' interest and intention to devote an entire season to the issue of violence against women. Both examples involve sexual violence and sexual harassment in workplace, which are particular kinds of VAW, blurring the line between the public and the private. As Kilmartin and Allison (2007:26) contend,

[a]s with all gender-based violence, sexual harassment involves an abuse of power. Men are much more likely than women to offend because they are more likely to be in position of organizational power, such as in the role of supervisor or manager. Moreover, the culture of masculinity influences men to (a) view women as subservient and as sexual objects, (b) to associate manliness with dominance, and (c) to view sexual activity as enterprise in which they must persistently pressure women until they achieve a conquest. The workplace provides daily opportunities of access to potential targets.

To a certain extent, the series reflects upon these circumstances of sexual harassment. 
In Season Two (which contains thirteen episodes), Monika has an affair with a colleague from work, who turns out to be aggressive towards her - first physically, especially under the influence of alcohol, and later on also psychologically (if sexually, it remains unclear). As a consequence, Monika gets pregnant (which comes as a surprise to her), but at first she does not know who the father is - her loving partner or the aggressive lover. Despite the fact that Monika experienced violence (she was beaten and possibly raped), she does not report the perpetrator to the police (as he promises to leave her and leave Poland) and decides to keep the baby. In Season Three, the perpetrator is back and when it turns out that he is the father of the child, he starts to blackmail Monika and demands to see his daughter. Shockingly enough, he is not only given a chance to take care of the baby, but also to redeem his violent behavior, which is them completely forgiven and forgotten in the course of the season. He even becomes a likeable character. What is striking in this example is that nobody in Monika's surroundings tries to persuade her to report the act of violence to the police; neither her partner, not her sister. As a result, "negative responses include both active and passive support of her abuse and for her abuser. Others may collude and encourage her abuser or refuse to intervene, thereby conveying a message of support for the way things are" (Hanmer 1996:13).

Season Five (eleven episodes), whose whole main plot revolves around the sexual violence experienced by Monika, depicts the issue in a completely different way. To my mind, not accidental is the fact that by dint of \#MeToo such plots and their more in-depth treatment are considered important and attractive to both producers and viewers. There is no doubt that television producers are rating- and income-oriented, hence their choice of such a contemporarily debated topic is not surprising.

In the first episode, Monika is raped by the (at first) unknown man, who drugged her by adding a rape pill to her drink at the company's party. She does not remember much and she is, obviously, traumatized. There are a few aspects of the depiction of violence against women - in particular sexual harassment at work and Monika's struggle for truth and the punishment of perpetrator - that I find progressive in this part of the series.

First of all, Monika tries to report the rape at the police station the day after. The way she is interrogated corresponds with many real-life experiences of women that were humiliated by the police and whose behavior, past, habits, clothing, etc. were questioned. Monika was falsely accused of possessing drugs in the past and this is used against her during the interrogation. The following conversation with the policewoman (!) illustrates the ways in which the victim's testimony is successfully undermined, doubted, and disregarded:

Policewoman: You said you woke up in an unknown room and found this note there, is that correct?

[The note says "Thanks. You were fucking great"] Monika Borecka: Yes.

$\mathrm{P}$ : There is a problem. You rented this room yourself. MB: That's not possible.

P: Perhaps you were under the influence or somebody talked you into it. I have checked and in the past you were charged with drug possession.

MB: I have been cleared of all the charges.

P: I will have to refer you to the hospital for tests, perhaps we will find traces of semen.

MB [crying]: You will find nothing, I took a shower.

P: Impossible, that is a huge mistake. 
MB: You want to lecture me now?

P: I only want to say that the room is surely long cleaned by now, we have only your dress, we don't know whether there are any traces on it...

MB: Right. I should come to you right after this happened, preferably with stained sheet in my bag.

P: I just want to say these traces are inconclusive and it is gonna be a hard fight. Even more so as you don't have a clean record.

MB: Right, now tell me it is my fault and I asked for it. I need to leave, I'm sorry. (S05E02) ${ }^{9}$

The conversation with the policewoman reflects the line of thinking that is based on victim-blaming a very common attitude towards raped women. Not only are Monika's behavior and past considered the problem here, but she is also expected to provide evidence to prove that the rape took place. Not surprisingly, after the conversation with the policewoman, Monika is traumatized and full of self-blame. The police does help her at last (towards the end of the season), but only because one of Monika's friends is a cop.

Throughout the whole season, it is implied that the responsibility to find the guilty person and to provide evidence to his violence lies with the victim. Even the prosecutor, who is on Monika's side, wants her to convince witnesses and gather evidence:

Monika Borecka: I was not the only one.

Prosecutor: Other women will testify as well?

MB: I don't know.

P: You have to talk them into testifying, otherwise this guy is going to get away with this. (S0509)

This conversation also shows that Monika's statement alone is not sufficient; it is not believed in.

${ }^{9}$ The translation of all the quotes from the series is mine.
Therefore, it is necessary to find other women who could confirm her story and tell their own histories of abuse.

Furthermore, A Second Chance provides much more information about the perpetrator than other television accounts do. He has a managerial position in the company and his mistreatment of women is characterized by Weinstein-like behaviors: forcing to have sex, recording intercourses, blackmailing the victims with the threat to publish the recordings, threatening to fire women, as well as other forms of humiliation in public and in private. When Monika finally remembers what happened to her that night, she confronts her abuser at the elevator in their workplace:

Marek Strzałkiewicz: What do you want from me, woman?

Monika Borecka: I remember everything now. It took me a while but I am certain now that it was you.

MS: Memory can be tricky. And imagination can tell stories which never happened.

MB: Don't lie. You put the drug into my drink. You did this to me.

MS: You want to report me? They will laugh at you.

MB: You're sick. And I will make you pay for this.

MS: You are crazy, aren't you? You are accusing me, because you let somebody catch you in a hotel room.

MB: I haven't said anything about a hotel room.

MS: What are you going to do now?

MB: I'll do the right thing.

MS: You have no proof.

MB: Get lost.

MB: Nobody's gonna believe you.

MB: Get out of here. (S05E08)

Evidently, the rapist does not intend to back out or express any remorse; he keeps harassing Monika 
both in public and by texting her. Before the court case, he threatens to her: "You think you can win? I will walk all over you and you will not know what is going on. Like back then" (S05E09). After she confronts him, he sends her a text message: "If you go to the police, you will become an Internet star. I will share the film with you in the leading role" (S05E08); he encloses the link to the recording he had made during the rape.

What is more, the perpetrator's crime is not a oneoff incident; he is a long-term abuser with at least three known victims (thanks to whom Monika finally wins the case in court). This time television devoted more attention to the aggressor, which is usually not the case: "Our society has done a better job of supporting victims who come forward; however, victim and survivor interventions are not addressing the heart of the problem: the perpetrator" (Kilmartin and Allison 2007:33). In A Second Chance, the perpetrator's work environment is aware of his abuse, but turns a blind eye (both women and men). Even when interrogated in court, some of them refuse to support Monika. Therefore, the show represents VAW not as an individual momentary aberration, but, rather, as a systemic social problem of the patriarchal culture, one that is characteristic of particular professions and work environments. In this context, it is important to understand "how such violence has been accepted, condoned, normalized, an ignored by both individuals and institutions. It has been seen as a 'private matter'"' (Hearn 1996:24).

These observations are clearly confirmed when one takes a closer look at the way Monika is questioned in court by the perpetrator's attorney:

Monika Borecka: I started to feel dizzy, I was losing control. I was drugged with something that was prob- ably put into my glass. I felt I was not able to go home, that is why I rented a hotel room. In the morning... I woke up alone in this room, in the bed, in a shredded dress. There was a note on the bed "Thank you. You were fucking great."

Prosecutor: Is this the note?

MB: Yes.

Defense attorney: Your Honor, let me remind everyone that the graphological analysis of the note concluded that the author cannot be determined.

MB: The author is the rapist, Marek Strzałkiewicz.

DA: How much did you drink?

MB: Maybe two glasses of champagne.

DA: Perhaps this wasn't enough for you and you took drugs to have a good time.

MB: I don't need drugs to have a good time.

DA: But drugs are nothing new in your life. A few years ago you were charged with drug possession and distribution.

MB: I was cleared of all the charges.

P: Your Honor, this is irrelevant for the case. Ms. Monika Borecka is not a defendant in this case.

DA: Or perhaps it all looked differently: due to alcohol or drugs the party got out of hand, you rented the room, invited someone in and had sex with him.

MB: I didn't invite anyone and whatever happened in this room was without my consent.

DA: Did you report the rape?

[retrospect from the conversation with the policewoman] MB: I wanted to, but it was too difficult for me then.

DA: No biological traces of my client were found on your clothes that would suggest rape.

MB: Yes, but...

DA: Your Honor, the victim admits that she has no evidence of rape.

MB: I reported the rape a few weeks after.

DA: Since you were convinced that my client abused you, what were you waiting for so long? You were working with him as if nothing had happened. 
MB: It wasn't like that...

DA: Or perhaps you didn't report rape post factum, because there was no such incident? The subsequent report only aimed to discredit my client.

MB: I wasn't sure who did this. Now I know.

DA: On what grounds?

MB: When I was under the influence, I only had some flashes of memory. I remembered only bits and pieces. I had to collect them all into one logical whole to be able to reconstruct the events of that evening. I know that it was the defendant that raped me.

DA: The alleged rape, how long did it last? Five minutes, fifteen minutes, an hour, the whole night?

MB: I can't remember.

DA: If you don't remember, then how can you be certain that my client raped you?

MB: I have just told you everything ...

DA: Your Honor, I have no further questions. (S05E11)

Monika is called a liar, manipulator, drug user. It is suggested that she is a promiscuous, out-of-control, carless, fun-loving person. As I see it, A Second Chance successfully reflects the difficulties that victims have to face in real life in order to convince the law enforcement and the court of their version of the story.

Finally, what is unusual for typical narratives on VAW is that Monika gets support from her current partner, family (parents) and friends, and this time it is not only emotional and psychological support, but also assistance in getting through the difficult investigation and court case. I believe that the active role of her current partner in the healing process is of crucial importance as "the prevention of violence requires men to become involved. Because men are responsible for committing the majority of acts of gender-based violence, men must be primarily responsible for keeping it from happening in the first place and yet men seem apparently reluctant to become involved in this work" (Kilmartin and Allison 2007:33). Not only is the legal system represented as being helpful and necessary in order to get over trauma and seek justice, but it is also the case that both Monika and her partner seek psychological help and ask specialists about ways to deal with it. The following exchange between Monika and her therapist speaks volumes about the toll that rape takes on both the victim and her close ones:

Therapist: The fact that you decided to come here at all is a sign that you have taken the first step towards going back to normal. This means a lot.

Monika Borecka: I don't know how to begin. This happened during the company's party and since then I have been looking for him, I see traces of him in every man I meet. I'm scared, but I cannot stop. I have this feeling that I am going mad. The only thing that keeps me alive is my children and the thought I will find him. But I fear that this fight is killing me, that my partner will not endure it.

Therapist: Your partner came here to me, seeking help for you. This proves his maturity. You can rely on him. (S05E06).

Such an approach to VAW - when both a women and her partner try to deal with trauma and talk about it openly outside of home - has been really uncommon in television narratives to date.

Additionally, what I perceive as a non-schematic aspect of A Second Chance is the fact that Monika as the victim transgresses common stereotypes; she is broken and gets over the trauma slowly and gradually. Her pursuit to first get to know the perpetrator and then put him in jail seems to be making her stronger and stronger. Therefore, the show emphasizes the flaws of the legal system, but also the urgent need 
for the law enforcement to acknowledge and address the experiences of women that suffered from sexual violence.

All in all, I believe that $A$ Second Chance in its final season offers a novel and more progressive narrative on the question of violence against women. No other Polish series so far has tacked this issue with such a level of detail and sensitivity towards the victim and her quest for seeking truth and justice. However, I cannot end my considerations without a critical comment on another plot of the series, which is less important, but very significant in this context. Simultaneously to Monika's struggle to punish the rapist, her partner, Piotr, is accused by his unstable, blackmailing ex-wife of being a domestic abuser in the past. She later admits that the accusation was false; she wanted to force him to give her money to pay off debts. I understand that the show producers - as they promised through statements issued by the leading actress - wanted to depict complexities, sensitivities, and multiple operations of gender-based violence. I fear, nonetheless, that it might soften the overall meaning and social impact of $A$ Second Chance as the above-mentioned thread weakens the argument about violence against women, subtly placing a question mark over testimonies of women who claim they were sexually or otherwise abused.

\section{Concluding Remarks}

Research on television series is timely and important due to their wide cultural-forming roles, significant influence on - and interaction with - the society, their impact on the shape of public discourses, and the fact that their attract diversified audiences. Therefore, popular-culture scholars believe that television series - because of their huge viewership and popularity, but also their capabili- ty to present different plots and protagonists in all their complexities, ambiguities, contradictions not only maintain and legitimize the dominant social norms, values, or patterns of masculinity and femininity, but they also play an important role in transgressing fixed stereotypes and popular schematic images, questioning the existing social order, and popularizing alternative ways of looking at certain phenomena or social problems, such as violence against women.

As Kilmartin and Allison emphasize, "The maltreatment of a survivor of gender-based violence by the legal system and/or media, which are largely controlled by conventionally gendered men, is intimidating to other survivors, who may fear that they will be re-traumatized if they come forward" (2007:9). Importantly in this context, one should remember that some scholars insist on calling VAW "men's violence to women" as it is considered to be a core element of men's power and domination over women (Hearn 1996:22). It should also be noted that the criticism of discourses on VAW "implies a political critique of those responsible for its perversion in the reproduction of dominance and inequality. Such a critique should not be ad hoc, individual or incidental, but general, structural and focused on groups, while involving power relations between groups. (van Dijk 1993:252-253)

A Second Chance is a popular cultural product that considers VAW as a serious social problem and, in my view, has a significant potential to sensitize audiences by representing it in a relatively unbiased, complex, and nuanced way. At the same time, it fails to address its wider socio-cultural aspects resulting from patriarchal structures and gender inequality, which is what VAW scholars cited in this paper emphasize. As Teun A. van Dijk (1993) insists, 
[p]ower and dominance are usually organized and institutionalized. The social dominance of groups is thus not merely enacted, individually, by its group members, as is the case in many forms of everyday racism or sexual harassment. It may also be supported or condoned by other group members, sanctioned by the courts, legitimated by laws, enforced by the police, and ideologically sustained and reproduced by the media or textbooks. This social, political and cultural organization of dominance

\section{References}

Anderson, Irina and Kathy Doherty. 2008. Accounting for Rape. Psychology, Feminism and Discourse Analysis in the Study of Sexual Violence. New York: Routledge.

Cardwell, Sarah. 2007. “Is Quality Television Any Good? Generic Distinctions, Evaluations and the Troubling Matter of Critical Judgement." Pp. 19-34 in Quality TV. Contemporary American Television and Beyond, edited by J. McCabe and K. Akass. New York: I.B. Tauris.

"Druga szansa hitem TVN i Player.pl. Powstanie drugi sezon." 2016. Retrieved January 20, 2020 (https://www.wirtualnemedia.pl/artykul/druga-szansa-hitem-tvn-i-player-pl-powstaniedrugi-sezon).

Druga szansa, dir. Michał Gazda, Łukasz Kośmicki, 2016-2018, TVN.

Feuer, Jane. 1984. “The MTM Style.” Pp. 32-60 in MTM: Quality Television, edited by J. Feuer, P. Kerr, and T. Vahimagi. London: BFI Publishing.

Graff, Agnieszka and Elżbieta Korolczuk. 2017. “'Worse than Communism and Nazism Put Together': War on Gender in Poland." Pp. 175-193 in Anti-Gender Campaigns in Europe: Mobilizing against Equality, edited by D. Paternotte and R. Kuhar. London, New York: Rowman \& Littlefield International.

Grzebalska, Weronika. 2015. “Poland." Pp. 83-103 in Gender as Symbolic Glue. The Position and Role of Conservative and Far Right Parties in the Anti-gender Mobilizations in Europe, edited also implies a hierarchy of power: some members of dominant groups and organizations have a special role in planning, decision-making and control over the relations and processes of the enactment of power.

With all this in mind, it is a must that the power and dominance of certain media images and narratives with regard to violence against women should be constantly contested and questioned.

by E. Kováts and M. Pőim. Budapest:Foundation for European Progressive Studies (FEPS).

Hanmer, Jalna. 1996. "Women and Violence: Commonalities and Diversities." Pp. 7-21 in Violence and Gender Relations. Theories and Interventions, edited by B. Fawcett et al. London: SAGE.

Hearn, Jeff. 1996. "Men's Violence to Known Women: Historical, Everyday and Theoretical Constructions by Men." Pp. 2237 in Violence and Gender Relations. Theories and Interventions, edited by B. Fawcett et al. London: SAGE.

Hess, Amanda. 2017. "How Movies and TV Address Rape and Revenge." New York Times. Retrieved October 08, 2018 (https:// www.nytimes.com/2017/01/12/arts/television/how-moviesand-tv-address-rape-and-revenge.html).

Hughes, Sarah. 2014. "Rape on TV: A Justified Look at Violence Against Women or a Crude Plot Device?" The Guardian. Retrieved October 08, 2018 (https://www.theguardian.com/tvand-radio/2014/dec/13/tv-rape-portrayal-storm).

Kilmartin, Christopher and Julie Allison. 2007. Men's Violence against Women. Theory, Research, and Activism. London: Lawrence Erlbaum Associate Publishers. Kilmartin, Christopher and Alan D. Berkowitz (2005). Sexual Assault in Context. Mahwah, New Jersey: Lawrence Erlbaum Associates.

Konecki, Krzysztof T. 2011. "Visual Grounded Theory: A Methodological Outline and Examples from Empirical Work." Revija za sociologiju 41(2):131-160. 
Koss, Mary P. and Hobart H. Cleveland. 1997. "Stepping on Toes. Social Roots of Date Rape Lead to Intractability and Politization." Pp. 4-21 in Researching Sexual Violence Against Women. Methodological and Personal Perspectives, edited by M. D. Schwartz. London: SAGE.

Kováts, Eszter and Maari Pőim. 2015. Gender as Symbolic Glue. The Position and Role of Conservative and Far Right Parties in the Anti-gender Mobilizations in Europe. Budapest: Foundation for European Progressive Studies (FEPS).

Łaciak, Beata. 2013. Kwestie społeczne w polskich serialach obyczajowych - Prezentacje i odbiór. Analiza socjologiczna. Warsaw: Wydawnictwo Akademickie ŻAK.

"Małgorzata Kożuchowska: wątek \#MeToo w Drugiej szansie będzie głosem w dyskusji w bardzo trudnej sprawie. Chcemy pokazać różne oblicza kobiet i mężczyzn." 2018. Retrieved January 20, 2020 (https://www.wirtualnemedia.pl/artykul/malgorzata-kozuchowska-watek-metoo-druga-szansa-sezon-5).

Orr, Christopher. 2015. “Why Does Game of Thrones Feature So Much Sexual Violence? The Atlantic." Retrieved October 08, 2018 (https://www.theatlantic.com/entertainment/archive/2015/06/ game-of-thrones-sexual-violence/396191/).

“Ostatni sezon Drugiej szansy stracił 280 tys. widzów." 2018. Retrieved January 20, 2020 (https://www.wirtualnemedia.pl/artykul/koniec-serialu-druga-szansa-ogladalnosc-piaty-sezon).

Paniagua, José María Bernardo et al. 2007. “New Advances in Critical Discourse Analysis of Media Texts." Pp. 5-16 in Critical Discourse Analysis of Media Texts, edited by J. M. B. Paniagua et al. Aldaia: Universitat de València Press.

Paternotte, David and Roman Kuhar (2017). Anti-Gender Campaigns in Europe: Mobilizing against Equality. London, New York: Rowman \& Littlefield International

Qianbo, LI. 2016. “Theoretical Framework of Critical Discourse Analysis." Studies in Literature and Language 13(5):36-40.
Różalska, Aleksandra M. 2011. "Gender and Family Discourses in Polish Television Series in the Context of Catholic and National Values." Pp. 59-77 in Gender and Diversity: Representing Difference, edited by D. Golańska and A. M. Różalska. Lodz: Łódź University Press.

Rustad, Gry C. 2015. Mapping Scandinavian "Quality TV." Nordmedia Høgskolen i Hedmark. Retrieved February 10, 2020 (https://www. academia.edu/14199152/Mapping_Scandinavian_quality_TV).

Schwartz, Martin D. 1997. "Preface." Pp. ix-xvii in Researching Sexual Violence Against Women. Methodological and Personal Perspectives, edited by M. D. Schwartz. London: SAGE.

Seiter Ellen and Mary Jeanne Wilson. 2005. "Soap Opera Survival Tactics." Pp. 136-155 in Thinking Outside the Box. A Contemporary Television Genre Reder, edited by G. E. Edgerton and B. G. Rose. Lexington: University of Kentucky Press.

Sutherland, Georgina et al. 2015. “Media Representations of Violence Against Women and Their Children: State of Knowledge Paper" ANROWS Landscapes 15/2015. Sydney, NSW: ANROWS.

Sutherland, Georgina et al. 2016. "Media Representations of Violence against Women and Their Children: Final Report." Retrieved October 04, 2018 (https://www.anrows.org.au/publication/media-representations-of-violence-against-women-and-their-children-final-report/).

Talarczyk, Monika. 2013. “Uważaj na swoją dziewczynkę!” Dwutygodnik. Tygodnik Kultury 8. Retrieved January 31, 2019 (https://www.dwutygodnik.com/artykul/4677-uwazaj-na-swoja-dziewczynke.html).

van Dijk, Teun A. 1993. "Principles of Critical Discourse Analysis." Discourse E Society 4(2):249-283.

van Dijk, Teun A. 1995. "Aims of Critical Discourse Analysis." Japanese Discourse 1:17-27.

Wodak, Ruth. 2013. "Critical Discourse Analysis: Challenges and Perspectives." Pp. xix-xliii in Critical Discourse Analysis. Volume 1, edited by R. Wodak. Los Angeles, London: SAGE.

\section{Citation}

Różalska, Aleksandra M. 2020. “Violence against Women as Reflected in the Polish Television Series A Second Chance.” Przeglad Socjologii Jakościowej 16(1):28-46. Retrieved Month, Year (www.przegladsocjologiijakosciowej.org). DOI: http://dx.doi org/10.18778/1733-8069.16.1.03 


\section{Przemoc wobec kobiet w serialu telewizyjnym Druga szansa}

Abstrakt: Celem artykułu jest krytyczna refleksja nad współczesnymi polskim serialami telewizyjnymi, a w szczególności nad sposobami reprezentacji różnych przejawów przemocy wobec kobiet. Analizowanym w tekście serialem jest produkcja TVN Druga szansa, którą emitowano w latach 2016-2018. Badania medioznawcze wskazują na to, że media niezmiennie ukazują przemoc wobec kobiet, jej okoliczności i powody, jak również wizerunki ofiar i sprawców w stereotypowy, często sensacyjny, sposób. Autorka patrzy na przemoc wobec kobiet w wybranym serialu przez pryzmat ruchu społecznego \#MeToo, a także w kontekście debaty na temat „ideologii gender” w Polsce. Wnioski z analizy serialu wskazują na to, że przemoc wobec kobiet jest w nim potraktowana jako poważny problem społeczny i że ma on potencjał, aby uwrażliwić publiczność na tę kwestię przedstawiając ją w sposób niestereotypowy, kompleksowy i zniuansowany. Jednocześnie produkcja TVN nie uwzględnia w wystarczającym stopniu społeczno-kulturowych uwarunkowań przemocy wobec kobiet, których należy szukać w patriarchalnej strukturze społecznej i braku równouprawnienia kobiet i mężczyzn.

Słowa kluczowe: przemoc, kobiety, telewizja, Druga szansa, molestowanie seksualne, ofiara, sprawca 
